\title{
PARTICIPATORY RESEARCH IN THE MANAGEMENT OF TERRITORIAL DEVELOPMENT. INVESTIGATIONS IN LIVEZILE-RIMETEA MICRO-REGION (2001-2002 and 2007-2008)
}

\author{
Mihai Pascaru ${ }^{1}$
}

ABSTRACT: The aim of this study is to present some important aspects of the way in which participatory research may contribute to the management of territorial development, through the identification of problems and development opportunities in a given territory. We will first identify some epistemological and methodological aspects which regard participatory research as a means of action research. Next, we will uphold the idea of restoring the scientific research results as an instrument for the construction and promotion of local actors' participation in the development processes. To this end we will present extensively two series of research carried out in the LivezileRimetea micro-region (county of Alba, Romania), respectively the series of research between 20012002 and 2007-2008. As a result of this research we identified and developed the methodology of restoring of results through interviews or public debates, with a view to reinforcing the human support in the region under scrutiny.

Keywords: territorial development, participatory research, restoring of results, development opportunities.

JEL codes: O10, F10, P10, N13

\section{Introduction: Concepts and methodology: participatory research and restoring of results in development projects \\ Participatory research}

Participatory research must be seen as a fundamental component of action research, even if at times, as will be seen in the following, it is treated as a particular form of it.

If we are to deepen the epistemological aspects entailed by this topic, we first have to note that Paul Oquist starts from the assumption that "research is the production of knowledge". (Oquist, 1978, 144-145). He links the concept of research to those of action, policy and practice [Oquist wrote: "Action is the wilful change of a given reality. The action involves consequences that change a specific reality, regardless of whether the action is successful or not so as to modify the reality under discussion towards a given direction. Policy is made up of needs and interests, values and norms, results and objectives, plans and programmes, operations, evaluations and resources concerning a given or a potential action. Practice is a policy and action in the context of determined processes and structures, both being acted upon and conditioning the results of actions" (Oquist, 1978, 144-145).]. By involving all the four concepts, Oquist identifies several types of research, among which descriptive research, political research and action research: "Descriptive research delineates the phenomena of incidents and events typology... Political research is the production of knowledge which guides practice, with changes of a given reality, but which takes place independent of, and generally subsequent to the process of research. Action research is the production of knowledge which guides practice, with changes of a given reality, which takes place as part of the research process" (Oquist, 1978, 145).

\footnotetext{
1 „1 Decembrie 1918” University of Alba Iulia, m pascaru@yahoo.com;
} 
In a study dedicated to action research models and methods (action-oriented research), Stephen A. Small described four situations: action research, participatory research, empowerment research, and feminist research. Small considered that, of the four mentioned models, action research is probably the most widely used. According to Small, historically speaking, action research was associated with the economic field and with organisational development. More recently this approach has also been used by specialists from other fields, such as education, agricultural innovation and human development. (Small,1995, 941-942).

Action research is one of those perspectives closely linked to social change. The most frequently used terms to define research which aims at changing the societal situations, according to Senn, are those of action research, participatory research and activist research. (Senn, 2005, 357).

Bridget Somekh characterised action research through its methodology: "Action research methodology delineates the limit between research and practice (Somekh, 1995, 340).

Action research necessarily involves participation, and "to participate means breaking, willingly and experientially, the asymmetric relationship of submission and dependence, implicitly existent in the pair subject/object” (Fals-Borda, 1987, 332). For both Argyris and Schön ,participatory action research is a form of action research which involves practitioners both as subjects and co-researchers" (Argyris, Schön, 1989, 613). According to Dentith and his colleagues, ,participatory research is base on collective investigations, native knowledge, community policies and collective action" (Dentith et al., 2009, p. 158).

Action research is seen as "ethic and political engagement in practice" (Fox, 2003, p. 87); the practitioners' engagement generating what Fox calls collaborative action research which can: 1) bring together people with diverse abilities and knowledge; 2) demystify the research process, allowing the practitioners to identify the process of data collection; 3 ) build a research capacity in a community which can operate/act independently; 4) increase the chance for practitioners to use the results and 5) improve the quality of research through facilitating the access to key entities which hold knowledge in a community" (Fox, 2003, p. 88).

McIntyre signals the following principles, specific to the field of participatory action research: 1) collective engagement to investigate the problem; 2) engagement desire in self- and collective reflection to gain clarity on the issue under scrutiny; 3 ) a common engagement decision into collective and individual actions which will lead to useful solutions, beneficial to those involved; 4) development of alliances between researcher and participants in planning, implementation and dissemination of the research project (McIntyre, 2008, p. 1).

\section{Restoring of results}

The restoring of results of academic research can be an important moment and instrument in participatory research for management of territorial development. (Buciuman, Pascaru, 2003; Pascaru, 2003; Pascaru, Buțiu, 2007).

We find references to the restoring of the results of a research as early as the $7^{\text {th }}$ and $8^{\text {th }}$ decades of the last century, in a France which made considerable efforts to support rural renovation.

The importance of a prior well-done rural inquiry, according to the French psychosociologist Roger Mucchielli, raises so much the more that the feed-back of an inquiry i.e. the restoring of the conclusions to the people where the inquiry was made (while the people accepted the inquiry itself), can provoke the raising of the local dynamics. From this point of view, according to the French psycho-sociologist, the rural inquiry represents the decisive event. If the inquirers know how to get the villagers cooperate and accept the inquiry from the very beginning, if they know how to involve the local informal and formal leaders, if they re-inject the results (and if the citizens recognize themselves in this image), a push is then given in order to make the change (Mucchielli, 1976, p. 73).

The complexity of the restoring is, unfortunately, but rarely approached. 
Bernard Bergier noticed that the more the research manuals and other methodological guides speak about media and offer advice for the settlement and organisation of data collection, the more the relation with the beneficiary and its impact upon the sociologist and the ethnologist. (Bergier, 2000 , p.5). The beneficiary focused on by the restoring is represented by the researcher's interlocutors in the field.

Bergier was wondering about the aim of restoring: Is it an ideological instrument, a stimulating procedure or a form of participative management of the researcher? Is it a convention which allows paying the debt to the investigated population? Is it a strategy of complementary investigation, where the restored content is to serve the stimulation to produce and collect new material (information)? Is it a test which allows that the restoring of results be accomplished by separating truth from falsehood? Is it a space of confrontation between likelihood and the research hypotheses?

In short, Bergier was wondering whether we should consider restoring as a constitutive element of the research or as an act outside it?

Bergier will propose the following definition for restoring: "...That act or dynamics through which the researcher shares the partial and/or definitive results of the worked collected data with the aim of their analysis, to his interlocutors in the field. (Bergier, 2000, p. 8).

\section{Participatory research projects in the economic field}

One of the best known participatory research projects in the economic field is the Mondragón - Cornell project, in which Cornell University and The Cooperative Complex Mondragón from the Basque region of Spain were involved as fully active participants (White et al., 1989, pp. 526-527).

The development of the Mondragón complex started in 1943 with the setting up of a small vocational school which now has become post-high school and now prepares students in the field of engineering and offers post-graduate studies in a business school set up later in 1960. The first workers' industrial cooperative, Ulgor, was set up in 1956 by five of the first students who started the technical school in 1943. From that modest beginning, the Mondragón complex now reached over 100 workers' industrial cooperatives, having at this moment more than 21000 hired workers.

This complex attracted the attention of specialists from Cornell University since 1975, and the basis for the participatory research project was laid between 1983 and 1985. The project had at the beginning strictly academic objectives, later on evolving through the integration of some practical objectives, at the imitative of the Mondragón managers, who were facing already a series of problems which could endanger the efficiency of the cooperativist organisation structure.

In 1985, the multidisciplinary study group set up at Mondragón comprised fifteen members of the cooperatives, the declared objective being that of elaborating a monograph. Once finished, the monograph was submitted to debate to those whose life it reflected. In the end it was clear that it was necessary to extend research through inquiries and interviews which will generate larger participation. The interviews were structured so as to confront these dilemmas concerning equality, equilibrium between social and economic interests, participation and so on, which the members of the cooperative already considered as sources of both dynamism and conflict (White et al., 1989). The main topics referred to: "(1) "value-added" to become a member of a cooperative: What does it mean, not only to have a job, but to be a member of a cooperative as well?; (2) Evaluation of communication inside individual cooperatives; (3) Economic and organisational re-adjustment problems.

If initially research was a major interest of academics, it has gradually become a central objective of the beneficiaries. In time internal sources of budgeting will be identified and personnel will be trained to develop at Mondragón endogenous participatory research projects.

Another participatory research project was presented by Fals-Borda. In this project participation was necessary in order to collect correct data in a census from El Regadio, Nicaragua. 
At the same time the aim was to raise respondents' awareness as to the traditional authority systems: "Thus, the process of change in El Regadio became more dynamic and people could assume new tasks for more efficient and more confident self-development" (Fals-Borda, 1987, 332). The impact was also positive on research results: "If old submission and dependence patterns hadn't been broken in El Regadio, the community census would have failed because the respondents would have given wrong answers. Resistance and suspicion disappeared when people realised that the interviewers were community members... If people from other places had come to do this, the investigation would have failed because there are people here who believe that most outsiders come here just to steal, rightfully concluded the commission" (Fals-Borda, 1987, 332).

2002

\section{Restoring of results of the research carried out in Livezile-Rimetea microregion, 2001-}

The research from 2001 to 2002 was carried out as part of the European project Eugenia.

The Project Eugenia was launched at the end of year 2000 within the program EcosOuverture. The theme of the project was inciting from the very beginning: lying the bases of an Inter-Regional Observatoire of Diagnosis and Territorial Action. (Observatoire Interrégional de Diagnostic et d'Action Territoriale). The aimed cooperation domain was described as being that of improving the work methods and instruments of the regional or local collectives in the domain of the development strategies of the territory.

Four themes of work were initially established within the project: Theme no.1: Instruments and methods of diagnosis and territorial action; Theme no. 2: territorial intelligence for development; Theme no. 3: The development of new agricultural channels and the diversification of activities Theme no. 4: Protection through valorisation of the natural and anthropic patrimony. In time, a fifth theme proved necessary: Communication (for the promotion of the project).

For every theme, a series of actions under the generic title of experiments (experimentations) was designed, aiming first at the collection of data, then at the analysis, diagnosis and projection of certain strategies for the implementation of a possible practical dimension of the project.

The experiments designed for Theme No.4 (Protection through valorisation of the natural and anthropic patrimony) were made in Romania, in the Depression of Trascău, in the villages Vălişoara and Izvoarele (the commune Livezile) and in Colţesti and Rimetea (the commune Rimetea). The space delimited in this way will be called from now on as the micro-region Vălişoara-Rimetea.

The territory of the micro-region Vălişoara-Rimetea, situated in the Northern half of the Trascău Mountains, has a surface area of $97.38 \mathrm{~km}^{2}$. The villages Rimetea, Colţeşti and Vălişoara are crossed by the County Rd. $107 \mathrm{M}$ and Izvoarele is one $\mathrm{km}$. West from the county road. At the time of the experiments, this road was so degraded that if somebody wanted to get to the county capital Alba Iulia, some villagers in Rimetea preferred to make a detour through Buru-Turda (Cluj county). Agriculture is the main occupation in the region. The agricultural land is parted in arable, pastures, hayfields and orchards. Part of the private hayfields was the object of the real estate transactions with those who built holiday houses and pensions in the region. The micro-region is favourable for fruit-growing, being prevented form strong winds. The animal raising is restricted in the protected regions: The Vălişoara Gorges, The Plai Gorges, The Siloş Gorges. In the period prior to the experiments within the Project Eugenia, the population of the micro-region was of 1472 villagers (Izvoarele: 200 villagers, Vălişoara: 210 villagers, Colţeşti: 599 villagers, Rimetea: 463 villagers). The demographic phenomena with direct consequences upon the socio-economic situation of the region were the decrease in the birth rate and the great ageing of the population. Under ecological aspect, the micro-region was affected by the presence of waste dumps on the banks of the river and by the lack of WWTP's. 
A first objective established at the projection of the inquiry was the construction of an illustrative lot for the region in which it was to take place, in the context of some material limits and some well shaped human resources.

In our research in the micro-region Vălişoara-Rimetea, several items were meant to describe the local resources at the level of the household (available rooms, renovations, available food resources etc.) from the perspective of the valorisation of the natural and anthropic patrimony by means of tourism development.

But, our interest was especially focused on the identification of the local problems.

As for the problems that should be solved within the village and commune, the hierarchy looks as follows: 1 . Roads: $43 \%$ of options, 2 . The water supply: $18 \%$ of options, 3 . Fixed phone: $16 \%$ of options. $3 \%$ declared that there was no problem and $17 \%$ declared there were other problems (Table 1).

Table no.1

Problems which should be solved in the micro-region

\begin{tabular}{|l|l|l|}
\hline \multicolumn{1}{|c|}{ The problem } & \multicolumn{1}{c|}{ Options } & \multicolumn{1}{c|}{$\%$} \\
\hline Roads & 138 & 43 \\
\hline Water supplies & 59 & 18 \\
\hline Telephony & 52 & 16 \\
\hline Mobile telephony & 10 & 3 \\
\hline Other problem (State which) & 54 & 17 \\
\hline Total & 322 & 100 \\
\hline
\end{tabular}

Starting from the results of the inquiry, the individualised restoring relied on an interview guide at the level of instruments. With the help of this instrument specific for the qualitative research, we tried to get new information which the questionnaire inquiry could miss.

Thus, we found out that the main cause of the money problem (identified as early as the stage of direct observations, which preceded the inquiry) was considered the lack of jobs: "It takes a job to earn money; working the land and raising the animals are not enough because we cannot sell the products".(S. A., Vălişoara).

It was often appreciated that the solution to the signalled problems (the lack of money etc.) did not depend only to each individual but to the development of the region as a whole, but what the phrase "the development of the region as a whole" really means is rather vague.

In the villages Vălişoara and Izvoarele, the lack of money was associated to age and illness, with the lack of labour power. Many young people were at work abroad or in towns in the neighbourhood, the lack of comfort at home making them go away from the village.

In this region as well, the idea of the "saving investor" was very strong: "If nobody comes here to make investments, we have no choice. We need investors."(N. I., Colţeşti).

New problems brought to discussion were Radio and TV reception.

As for the water supply, we were signalled to the almost incredible fact that some villagers gave up the commune network and dug their own fountain. The causes of the water supply problems in the local network were to be found in exactly the accomplishment of the work: "The villagers worked superficially when the work was done, and, at present, the pipe is very old, leaks and must be changed, as it has never worked well.” (S.A. Vălişoara). In Izvoarele, there were no water problems, and, beyond that, it was suggested that the local source can supply the villages Colţeşti and Rimetea as well.

In Colţeşti, people signalled the fact that "the water was interrupted by the villagers, especially by the diary and by the greenhouse owners, who put up hidrophores and consume a lot of water" (G. S., Colţeşti). (Solutions: the cleaning of the present pools and the replacement of the feed pipe, the fitting-out of special basins for those who consume large quantities of water. It was 
considered in Colţeşti that a communal system is the only solution: "It is very expensive to dig your own fountain." (V.I., Colţeşti).

Throwing the remains in improper places was not considered normal in Vălişoara, but it did not represent, at least for a part of them "a priority problem" (S. A., Vălişoara). Some of them did not consider it necessary to make a special place: "The domestic waste problem is a personal problem". (M. A., Vălişoara). In Izvoarele, a villager admitted: "Here all the waste is thrown in the valley and when great waters flow the valley, all of them are taken to the Mureş" (B. S., Izvoarele). Another villager remarked: "Many throw the domestic waste in the rivulet as it crosses their yard and they consider they throw it in their yard". (A. C., Izvoarele).

Here there is a problem of constructing the research instruments for the definition of what yard means, this aspect being anticipated.

In Colţeşti, the cleaning problem was seen as a common sense problem. Here the need of a common pit was more frequently invoked than in other villages. Another solution: litter bins and taking the litter periodically with a machine from Aiud. (P. I., Colţeşti).

In Vălişoara there were villagers who did not see tourism as a solution for the future of the micro-region. Among those who declared that had accommodation rooms, some would have wished the implementation of some European programs (for the development of the whole region. The accommodation available for tourists meant money for renovation: "We should appeal to foreign companies to help us as we don't have money.'(C. G., Izvoarele).

The villagers in Izvoarele seemed envious of the villagers in Rimetea, but their hope was in them: "The Hungarians in Rimetea are ahead us with their beautiful, furnished houses. We need bathrooms, separate rooms and we have no such conditions in our village. So we need investment. They must start in Rimetea and then come here."(A. C., Izvoarele).

In Vălişoara, some villagers appreciated that supplementary income was very unlikely. There few who managed to sell some agricultural products in town. Somebody would open a dressmaker's "to serve several villages as in Vălişoara there are few young people" (M. A., Vălişoara). Under the circumstances, the lack of medical assistance is brought to discussion.

In Colţeşti a special problem seemed that of product selling:’'It would be better if we could valorify what we cultivate: fruit, wheat, poppy, flowers, vegetables. They should bring us in the village to make a contract with in order to sell our products, for example a contract with the company PLAFAR for poppy. (N. I., Colţeşti).

In Rimetea, the museum ensured the selling of some traditional cloths. But the lack of a market was generally felt also regarding traditional products: "We could work something at home hand-sewing, especially in winter. There are hardly other chances. In the times of the collective, we had more money.”(D. I., Colţeşti).

In the end, tourism seemed to be the only chance and all the others were subordinated to tourism, including agriculture: "Nothing can be made here except for tourism. A goat farm would be useful as tourists keep on asking for goat cheese." (C. A., Rimetea).

In Rimetea, there were problems signalled regarding the banks when it was about sustaining agricultural development: "We tried a loan in dollars from the FIDA program (up to 10000). The Agricultural Direction checked me up. At the commercial bank in [...] I endorsed a house and an apartment in Alba Iulia, with two endorsers, and after two months the bank called me again to bring two more endorsers with a salary of 7 million lei a month, which was impossible to me, and my file was rejected. This is the way we get help for development." (C. I., Rimetea).

The hierarchy of the regional problems was different for one of the leaders of the village Izvoarele: "The most urgent problem is that of the TV reception. The colour TV doesn't work, nor does sound. Then the problem of roads and telephones (the villagers are depressed because of the lack of telephones.)"(V. A., Izvoarele).

In Colţeşti, G. St. stated the following: "The classification [of the micro-regional problems] is good, but we limit ourselves only to classify the problems without solving them. All problems are 
vital, they are highly important; there is no more important one. I don't think that any of the problems above can find a solution at local level, they can be solved only with the intervention of the state."

As for the group restoring in Rimetea (June, 2002), in the seminar attended by villagers of the researched micro-region, local authorities, representatives of the county authorities, internal experts and the coordinators of the project at European level, analysed the data taken from the quantitative analysis of the inquiry results (presented as tables and graphics), where the stress was laid on the following dimensions: 1) personal and family problems 2) problems specific for the entire micro-region 3) ecological problems (difficulties related to the water supply and the palce where dirty water and domestic waste were thrown) 4) the main activity domains which could develop in the micro-region.

The discussions began with the problem of water. It was appreciated that indeed water did not get to every household, but it was not because of the malevolence of the people, as experts had suspected and suggested, but because of a series of technical problems. The vice-mayor of the commune Rimetea brought extra-information: "The initial project involved only the police-station. Then, people got involved and with the help of the party they did the work. They brought pipes from where they could (some of them were out of use) and they did not last long. They broke in time and now there are great water losses. Moreover, the consumed amount increased in every family, water being used for washing, garden and animals. I proposed to buy water meters and we got them with the help of our friend abroad. But we cannot set them in people's households as they already have water at home and they do not agree. With a team from Hungary we measured the water discharge. 10 litters of water flow in 16 seconds. Where does all this water go? When the water was put up, the water discharge was enough. A regulator would be necessary as it would regulate the water discharge in the whole village. In Rimetea, the authorities tried to introduce a tax of 10000 lei per month for common villagers and 100000 lei per month for people who accommodate tourists, but many people considered the measure unfair." The representatives of the County Council remarked the fact that there was legislative support for such a measure, so it was fair.

The people in the Romanian villages, such as Izvoarele appreciated the existence of the milk processing factory in Colţeşti: "But for the factory in Colţeşti, we would starve." (C. G., Izvoarele).

A factor preventing the development was also the excessive fiscal policy: "I have a family business, but fiscal policy ruins me. I have a[n ice-cream] laboratory functioning according to the legislation and they still find problems during inspections. I think I will give up as I can't take it anymore. " (P. I., Rimetea)

Another restoring seminar was organised in Vălişoara on August, 25 ${ }^{\text {th }}, 2002$. On this occasion, the solution of the inter-communal cooperation was more clearly shaped. It also relied on the tensions existing at commune level in Livezile. The villages which promoted a certain dissidence towards the centre village were exactly Izvoarele and Vălişoara - the two villages our experiments focused on as well.

\section{Researches and restoring of results to leaders and local authorities (2007-2008)}

In 2007, at the level of our sample, $47.5 \%$ of our respondents appreciated that a major problem in the village is represented by roads, $19,7 \%$ by the water and sewage system, $4.9 \%$ unemployment and $2,7 \%$ waste management. In $87.4 \%$ of the case sit was considered that the identified problem directly affected the respondent's household.

Among the profit generating activities which may be carried out in the villages of the microregion the following were signalled: 1$)$ tourism $(53.6 \%), 2)$ agriculture $(23.2 \%), 3)$ industry $(2.7 \%)$, 4) other (5,7\%). See Table 2. 
In $62.0 \%$ of the case sit was considered that any one of the activities will directly benefit the respondent's household.

Table no. 2

Profit-generating activities

\begin{tabular}{|l|l|l|}
\hline \multicolumn{1}{|c|}{ Activities } & \multicolumn{1}{c|}{ Options } & \multicolumn{1}{c|}{$\%$} \\
\hline Tourism & 196 & 53.6 \\
\hline Agriculture & 85 & 23.2 \\
\hline Industry & 11 & 3.0 \\
\hline Crafts & 10 & 2.7 \\
\hline Other & 21 & 5.7 \\
\hline NS/NA & 43 & 11.7 \\
\hline Total & 366 & 100.0 \\
\hline
\end{tabular}

In the restoring interviews, some leaders and representatives of local authorities were presented, for each village, the hierarchy of the main local problems, followed by this set of questions: Are these priority problems? If not, which are the most important problems which need to be solved in this village? How does the local administration address these problems?

In Livezile, the problems identified were confirmed in general terms most of the times: "Something of the kind. These are the problems approximately. But this holds true not only in our village, but in the whole country." (30 years, M, councillor, Livezile); "They are totally true. Infrastructure refers to roads. In order to develop an area, such as ours with ... first of all we need good infrastructure so that those who want to see, to have way of access". (B, 60 years, B\&B owner, Livezile).

For Livezile, an explanation of the problematic status quo is found in the past: "Livezile communality was non-collectivised; it has been left with an old mark from the communist regime, as it was uninteresting to the then leaders. The only good thing that was done was the water system..." (53, M, councillor Livezile).

Other problems were signalled at Livezile too: "For all the villages the first problem is represented by the abandoned land... Traffic: truck are loaded from the quarry, the quarry has been abandoned and houses get cracks because the trucks have 30 tons. Dams: Two floods occurred in 2005 and 2006. A project run by the National Water Company was supposed to be going on, but is has been stopped for lack of funds... There is now sewage system in any of the villages. In Livezile there is a surgery, but the GP does not come because he works for Aiud too... The environment: Between 2000 - 2004 each spring, people used to receive a notification to clear away dried remains and burn them, not to throw them downhill. People still do this, despite the dust bins which have been installed... People are not civilised. It can be seen whether a communality has been collectivised or not through people's level of civilisation." (53, M, councillor, Livezile).

Concerning the road Aiud-Livezile-Rimetea, a problem the micro-region faces is the fact that political factors hinder the access to European funds: "The road should enter into auction for European funds, that is 7 million Euro, but there have been political problems about this road since 2000, because such is life in politics.” (53, M, councillor, Livezile).

Among future projects in Livezile, one could mention the resurgence of local extraction industry: "All youth have left the village... They left because they have no money and have nowhere to work. Look, the poor quarry has got plenty of stone, but we go and take stone from others, from 50-60 km away and our stone is just here..." (58, M, councillor, Livezile).

Not all local leaders are optimistic about the future: "Projects? We should try some European funds through which we could solve the infrastructure problem and the hydrographical networking of the area. Concerning infrastructure, some projects have been submitted, but up the present nothing has been solved. For the time being, promises galore..." (M, 60 years, B\&B owner, Livezile). 
A complex characterisation, with explanations about different layers was given by one of the priests in Livezile: "These are broadly speaking the problems: the road, the traffic ... they stem not only from a lack of resources, but also from the narrow mentality of the Romanians. Romanian society, even before 1989, he who a job, used to steal from there... Then the lack of unity between people; people were not used to pool anything together... There are people who could afford to cultivate very large land surfaces, but others are not willing to give theirs... (29, M, priest, Poiana Aiudului, Livezile).

As far as projects are concerned, the priest considers the water supplies and the roads as starting points: "As far as I know, there has been a project for the water system, amounting to 500 million. Water pipes were to be built somewhere from Izvoarele, for the whole communality: Izvoarele, Poiana, Livezile. The county road is not run by the City Hall, but by the County Council, the money was allotted. The auction was made; we then waited for the money to dry up. So that they could afterwards say that they had run out of it. This is what happens in our country, we first build the road, then we break it down to install the sewage system..." (29, M, priest, Poiana Aiudului, Livezile).

In Rimetea, some local leaders saw the hierarchy of problems in a different way: "I would say that garbage is the most important problem. Domestic waste, to be more precise... everywhere, if you have been outside the village, you must have seen that people throw the garbage outside. You can't fine people because there's no place to take garbage away. This must be it, it's a problem" (42, M, councillor, Rimetea); "The most important problem to me is agriculture, so the state of agriculture... Here we should, we have discussed, an associated could be created, for people to labour the land, two-three hectares to be able to make some contract with somebody and to be able to turn to good account what they produce..." (M.I., 53, M, businessman, Colţeşti, Rimetea).

Some of the leaders in Rimetea even wanted to impose their hierarchy: "The main, ardent problem of the Rimetea communality is running water and sewage, next can be anything else, but first come water. I will give you just an example: until today, since last week we have had no water, I couldn't take a shower... If one has running water, one can cook, one can clean, to have a clean environment, to feel food, and then one could do anything... If one is dirty, they cannot go anywhere, there's no use going if they're dirty" (KI, councillor, Rimetea)

Other problems signalled in Rimetea: "Here at Colţeşti there is a surgery, but the problem is not the surgery room, but the family doctor. The family doctor caters for Rimetea, Colţeşti and Aiud. One day per week..." (42, M, councillor, Rimetea); "Fuel provisions are problematic, especially for the poor ones, for the pensioners... We have no fuel, just wood" (M.I., 53, M, businessman, Colteşti, Rimetea).

An unusual problem was also recorded at: "Well, from my personal point of view, most of the inhabitants have their houses in brick, unfinished, that is. So if there were some funds for the facades facing the street to be a bit refurbished. Considering that we are in tourist area and it's a nice place, it would be more pleasant for the visitors to see nicer facades" (VM, 36, F, primary school teacher, Colţeşti, Rimetea).

The problems of the area involve, in the opinion of local leaders, a very important cultural component as well: "Education, starting from kindergarten and at least until the eight grade should be professional, not with substitute teachers or with teachers who do not care about the children's future" (SN, 39, m, businessman, Colţeşti, Rimetea).

A truly participatory democracy seems to be the fundamental solution according to some leaders in Rimetea: “...In my opinion we need to talk to people, ask for their opinion, and afterward only make a decision ... I cannot assume responsibility for the village, we need to talk, so that's what I think, this democracy should function like this: I ask the person, sir, what would you like to do? And then out of this, what we can to be successful ..." (M.I., 53, M, businessman, Colteşti, Rimetea). 


\section{Some conclusions}

Our investigations from 2001 to 2002 brought into discussion, for the first time in our country, the benefits and limitations of the restoring of scientific results to the human collectivities under scrutiny.

By restoring the results we identified the local problems, but most importantly for the management of territorial development was the fact that the local actors' representations of problems and chances concerning sustainability of development at local or micro-region came into shape. Moreover, when results were restored during public gatherings or through direct involvement of local authorities (during 2007-2008), the governors and the governed were faced with relevant scientific truths. The debates often shifted from the analysis of scientific information provided by the researchers towards the identification of practical solutions to the identified problems. We can say the the participatory dimension of research, both during the investigations during 2001-2002 and during 2007-2008, directly substantiated the participatory dimension of development. Let us remember in this context what Kumar already wrote in 1993: "Governments, financing agencies, donors, civil society actors including the ONGs and multifunctional agents such as the World Bank and the International Monetary Fund came to the conclusion that development can not be sustainable and long-lasting if only the people participation is part of the development process" (Kumar, 1993, p. 23).

\section{References:}

1. Argyris, Chris, Schön, Donald A. (1989), Participatory Action Research and Action Science Compared, ABS, American Behaviour Scientist, Vol. 32, no. 5, May/June 1989, 612-623;

2. Bergier, Bernard (2000). Repères pour une restitution des résultats de la recherche en sciences sociales. Intérêts et limites. Paris: Harmattan;

3. Buciuman, E., Pascaru, M., 2003, Dezvoltarea de noi filiere agricole şi diversificarea activităţilor economice în zona Abrud-Zlatna, final report to The Project Eugenia - Observatoire Interrégional de Diagnostic et d'Action Territoriale, Alba Iulia, Alba County Council;

4. Dentith, Audrey M., Measor, Linda, O’Malley, Michael P., 2009, Stirring Dangerous Waters: Dilemmas for Critical Participatory Research with Young People, Sociology, BSA Publications LTD, Los Angeles, London, New Dehli, Singapore, SAGE Publications, Volume 43 (I), 158-168;

5. Fals-Borda, Orlando, 1987, The Application of Participatory Action research in Latin America, International Sociology, Vol. 2, No. 4, December 1987, pp. 329-347;

6. Fox, Nick J., 2003, Practice -based evidence: Towards Collaborative and Transgressive Research, Sociology, BSA Publications LTD, Los Angeles, London, New Dehli, Singapore, SAGE Publications, Volume 37 (I), 81-102;

7. Kumar, K., 1993, „Civil Society: An Inquiry into the Usefulness of an Historical Term” in The British Journal of Sociology, Vol. 44, No. 3. (Sep., 1993), pp. 375-395;

8. McIntyre, Alice, 2008, Participatory Action Research, Qualitative Research Methods Series 52, Los Angeles, London, New Dehli, Singapore, SAGE Publications;

9. Mucchielli, Roger, 1976, Psycho-sociologie d'une commune rurale. Paris: Entreprise Modern d'Edition - Libraires Technique, Les Editions ESF;

10. Oquist, Paul, 1978, The Epistemology of Action Research, Acta Sociologica, Vol. 21, no. 2, 143-163;

11. Pascaru, M., 2003, „Diversitatea şi diversificarea în proiectul inter-regional european Eugenia. Contribuţii româneşti", in C. Pârlog, D.-L. Constantin (coordinators), Dezvoltare regională şi integrare europeană, Bucureşti, Editura Oscar Print, pp. 58-63;

12. Pascaru, M., Buţiu, C. A., 2007, Restituirea rezultatelor şi dezvoltarea comunitară, Cluj-Napoca, Editura Argonaut; 
13. Senn, Charlene Y., 2005, You can change the Word. Action, Participatory and Activist Research, F.W. Schneider, J.A. Gruman, L.M.Coutts, eds. În Applied Social Psychology. Understanding and Addressing Social and Practical Problems. Sage Publications: Thousand Oaks, London, New Dehli, 355-374;

14. Somekh, Bridget, 1995, The Contributions of Action Research to Development in Social Endeavours: A Position Paper on Action Research Methodology. British Educational Research Journal, 21(3), 339-355;

15. Small, Stephen A., 1995, Action-Oriented Research: Models and Methods. Journal of Marriage and the Family, 57(4), 941-955;

16. White, William Foote, Greenwood, Davydd J., Lazes Peter, Participatory Action Research. Through Practice to Science in Social Research, American Behaviour Scientist, Vol. 32, no. 5, May/June 1989, 513-531. 